\title{
Le journalisme au temps de la Révolution : un pouvoir de vérité et de justice au service des citoyens.
}

Gilles Feyel

\section{(2) OpenEdition Journals \\ Édition électronique \\ URL : https://journals.openedition.org/ahrf/843 \\ DOI : $10.4000 /$ ahrf.843 \\ ISSN : 1952-403X \\ Éditeur : \\ Armand Colin, Société des études robespierristes}

Édition imprimée

Date de publication : 1 septembre 2003

Pagination : 21-44

ISSN : 0003-4436

Référence électronique

Gilles Feyel, « Le journalisme au temps de la Révolution : un pouvoir de vérité et de justice au service des citoyens. ", Annales historiques de la Révolution française [En ligne], 333 | juillet-septembre 2003, mis en ligne le 20 avril 2004, consulté le 22 avril 2022. URL : http://journals.openedition.org/ahrf/843 ; DOI : https://doi.org/10.4000/ahrf.843

Ce document a été généré automatiquement le 22 avril 2022

Tous droits réservés 


\title{
Le journalisme au temps de la Révolution : un pouvoir de vérité et de justice au service des citoyens.
}

\author{
Gilles Feyel
}

\section{RÉSUMÉS}

Au-delà du premier journalisme d'information-célébration de la Gazette, la fin du XVIII ${ }^{\mathrm{e}}$ siècle voit se développer avec Linguet, mais aussi les gazettes étrangères périphériques, un nouveau journalisme, se voulant plus indépendant du pouvoir d'Etat et plus sensible à l'opinion. Au début de la Révolution et pour se libérer du pouvoir monarchique, les nouveaux journalistes - Brissot, Mirabeau, Marat - imposent leur pouvoir d'influence. Ils déclarent exercer une magistrature de vérité et de justice, trouvant sa légitimité dans le service des citoyens, et dans des normes éthiques assumées comme telles. Rien ne montre mieux ce rôle nouveau du journalisme que l'éloge funèbre de Camille Desmoulins, saluant la mémoire de son confrère Elysée Loustalot. Journalism during the Revolution : the Power of Truth and Justice at the Service of the Citizen Over and above the news-sheet's task to inform and celebrate, as in the Gazette, the late eighteenth century saw the emergence, with Linguet and also peripheral foreign gazettes, of a new brand of journalism intent on achieving greater independence from the state and reacting to public opinion. As the Revolution began, in order to shake off the power of monarchy, the new journalists - Brissot, Mirabeau, Marat - asserted the power of influence. They claimed to be acting as the magistrates of truth and justice, legitimized by the service thus rendered to the citizens and by the ethical norms defended in the process. There is no better illustration of the new role of journalism than the funeral tribute paid by Camille Desmoulins to the memory of his colleague Elysée Loustalot. 